\title{
Reclassification of Flexibacter tractuosus (Lewin 1969) Leadbetter 1974 and 'Microscilla sericea' Lewin 1969 in the genus Marivirga gen. nov. as Marivirga tractuosa comb. nov. and Marivirga sericea nom. rev., comb. nov.
}

\author{
Olga I. Nedashkovskaya, ${ }^{1}$ Marc Vancanneyt, ${ }^{2}$ Seung Bum Kim ${ }^{3}$ \\ and Kyung Sook Bae ${ }^{4}$
}

Correspondence

Olga I. Nedashkovskaya

olganedashkovska@piboc.dvo.ru

or

olganedashkovska@yahoo.com

\author{
${ }^{1}$ Pacific Institute of Bioorganic Chemistry of the Far-Eastern Branch of the Russian Academy of \\ Sciences, Pr. 100 Let Vladivostoku 159, 690022 Vladivostok, Russia \\ ${ }^{2}$ BCCM/LMG Bacteria Collection, and Laboratory of Microbiology, Ghent University, \\ Ledeganckstraat 35, B-9000 Ghent, Belgium \\ ${ }^{3}$ Department of Microbiology, Chungnam National University, 220 Gung-dong, Yusong, \\ Daejon 305-764, Republic of Korea \\ ${ }^{4}$ Korea Research Institute of Bioscience and Biotechnology, 52 Oun-dong, Yusong, \\ Daejon 305-333, Republic of Korea
}

\begin{abstract}
The taxonomic position of the misclassified strains [Flexibacter] tractuosus KCTC $2958^{\top}$ and '[Microscilla] sericea' LMG 13021 was studied using a polyphasic approach. The two strains shared $99.1 \% 16 \mathrm{~S}$ rRNA gene sequence similarity and $28 \%$ DNA-DNA relatedness. On the basis of the phylogenetic evidence supported by genotypic and phenotypic data [Flexibacter] tractuosus KCTC $2958^{\top}$ and '[Microscilla] sericea' LMG 13021 are classified as two distinct species in a novel genus, Marivirga, in the family 'Flammeovirgaceae', as Marivirga tractuosa comb. nov. and Marivirga sericea nom. rev., comb. nov., with strains KCTC $2958^{\top}$ (=ATCC $\left.23168^{\top}=\mathrm{CIP} 106410^{\top}=\mathrm{DSM} 4126^{\top}=\mathrm{NBRC} 15989^{\top}=\mathrm{NCIMB}^{\top} 1408^{\top}=\mathrm{VKM} \mathrm{B}-1430^{\top}\right)$ and LMG $13021^{\top}\left(=\right.$ ATCC $23182^{\top}=\operatorname{NBRC} 15983^{\top}=$ NCIMB $\left.1403^{\top}\right)$, respectively, as the type strains. The type species is Marivirga tractuosa.
\end{abstract}

Detailed analysis of the phylogenetic relationship between members of the genera Flexibacter, Flexithrix and Microscilla based on the comparison of 16S rRNA gene sequences has revealed their considerable heterogeneity (Nakagawa et al., 2002). These authors suggested restricting the genera Flexibacter and Microscilla to their respective type species, Flexibacter flexilis and Microscilla marina, while the other species previously allocated to these genera were considered potential members of novel species and genera or families. The name [Flexibacter] aggregans attributed to strain IAM $14894^{\mathrm{T}}$ (=IFO $15976^{\mathrm{T}}$ ) was recognized as a later heterotypic synonym of Flexithrix dorotheae, and '[Microscilla] furvescens' LMG $13023^{\mathrm{T}}$ was reclassified in the novel genus Marinoscillum as Marinoscillum furvescens comb. nov. (Hosoya \& Yokota, 2007; Seo et al., 2009). The genera Flammeovirga and Persicobacter were created due to reclassification of the species Cytophaga aprica and Cytophaga diffluens, respectively (Nakagawa et al., 1997). Taxonomic investigations of newly isolated marine bacteria served as a basis for emending the descriptions of these genera (Muramatsu et al., 2010; Takahashi et al., 2006). Moreover, the related genera
Fabibacter, Fulvivirga, Limibacter, Perexilibacter, Rapidithrix, Reichenbachiella, Roseivirga and Sediminitomix were described over the past few years due to extensive taxonomic studies (Khan et al., 2007; Lau et al., 2006; Nedashkovskaya et al., 2003, 2005a, b, 2007; Srisukchayakul et al., 2007; Yoon et al., 2007, 2008). The above-mentioned genera have recently been grouped in the family 'Flammeovirgaceae' (Ludwig et al., 2008; Yoon et al., 2007, 2008).

'[Microscilla] tractuosa' KCTC 2958 and '[Microscilla] sericea' LMG 13021 were first described by Lewin (1969). Leadbetter (1974) transferred '[Microscilla] tractuosa' to the genus Flexibacter but Reichenbach (1989) restricted this genus to the freshwater and terrestrial species, while its marine representatives were maintained in the genus Microscilla. [Flexibacter] tractuosus was included in the Approved Lists of Bacterial Names (Skerman et al., 1980) but '[Microscilla] sericea' was not.

The taxonomic investigation performed in this study on [Flexibacter] tractuosus KCTC $2958^{\mathrm{T}}$ and '[Microscilla] sericea' LMG $13021^{\mathrm{T}}$ by using a polyphasic approach 
showed that the strains should be placed in a novel genus as two distinct species, for which the names Marivirga tractuosa comb. nov. and Marivirga sericea nom. rev., comb. nov. are proposed.

[Flexibacter] tractuosus KCTC $2958^{\mathrm{T}}$ and '[Microscilla] sericea' LMG 13021 were routinely cultivated at $28{ }^{\circ} \mathrm{C}$ on marine agar 2216 (MA; Difco) and stored at $-80^{\circ} \mathrm{C}$ in marine broth 2216 (Difco) supplemented with $20 \%(\mathrm{v} / \mathrm{v})$ glycerol.

The almost-complete 16S rRNA gene sequences of [Flexibacter] tractuosus KCTC $2958^{\mathrm{T}}$ and '[Microscilla] sericea' LMG 13021 deposited in GenBank were aligned with those of representative members of selected genera belonging to the phylum Bacteroidetes by using PHYDIT version 3.1 (http://plaza.snu.ac.kr/ jchun/phydit/). Phylogenetic trees were inferred by using suitable programs of the PHYLIP package (Felsenstein, 1993). Phylogenetic distances were calculated from the model of Jukes \& Cantor (1969), and the trees were reconstructed on the basis of the neighbour-joining (Saitou \& Nei, 1987), maximum-likelihood (Felsenstein, 1993) and maximumparsimony (Kluge \& Farris, 1969) algorithms. Bootstrap analysis was performed with 1000 resampled datasets, using the SEQBOOT and CONSENSE programs of the PHYLIP package (Fig. 1).

Phylogenetic analysis revealed that [Flexibacter] tractuosus KCTC $2958^{\mathrm{T}}$ and '[Microscilla] sericea' LMG 13021 were

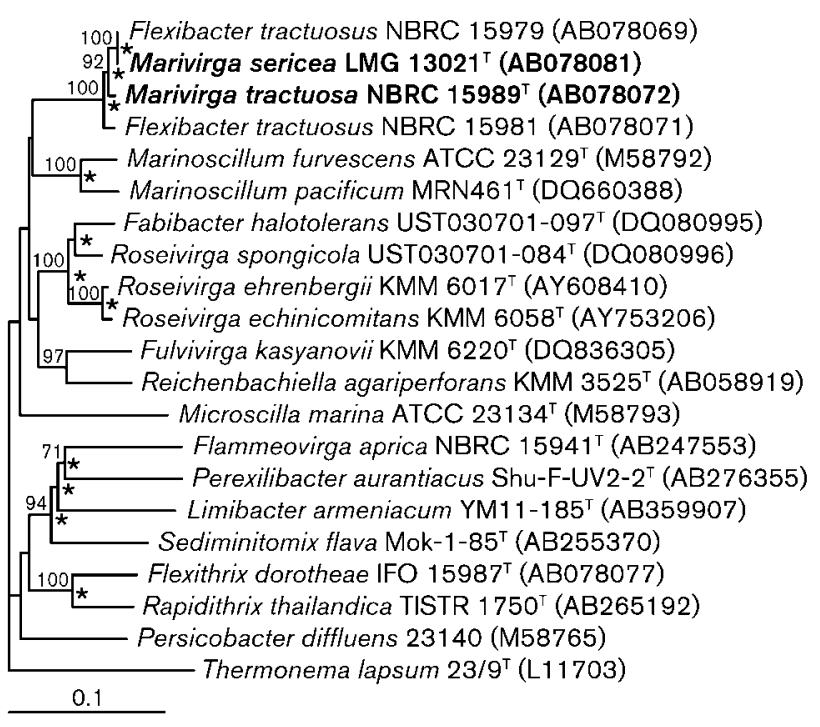

Fig. 1. Neighbour-joining tree based on 16S rRNA gene sequences showing the relationships of species of the novel genus Marivirga and representative members of the family 'Flammeovirgaceae'. Values at nodes are bootstrap supports $(>70 \%)$, and asterisks indicate branches also recovered in the maximum-likelihood and maximum-parsimony trees. Thermonema lapsum $23 / 9^{\top}$ was used as an outgroup. Bar, 0.1 substitutions per nucleotide position. most closely related to members of the genera Fabibacter, Reichenbachiella and Roseivirga, with 88.4-90.6\% $16 \mathrm{~S}$ rRNA gene sequence similarity, while the two strains shared $99.1 \%$ sequence similarity.

DNA was isolated following the method of Marmur (1961) and the DNA G + C content was determined by the thermal denaturation method (Marmur \& Doty, 1962). The values for [Flexibacter] tractuosus KCTC $2958^{\mathrm{T}}$ and '[Microscilla] sericea' LMG 13021 were 36.1 and $37.1 \mathrm{~mol} \%$, respectively. DNA-DNA hybridization was performed spectrophotometrically and initial renaturation rates were recorded as described by De Ley et al. (1970). The level of DNA-DNA relatedness between [Flexibacter] tractuosus KCTC $2958^{\mathrm{T}}$ and '[Microscilla] sericea' LMG 13021 was $28 \%$, confirming that they represent two distinct species of the same genus (Wayne et al., 1987).

For cellular fatty acid analysis, the two strains were grown at $25{ }^{\circ} \mathrm{C}$ for $48 \mathrm{~h}$ on MA. The analysis of fatty acid methyl esters was carried out according to the standard protocol of the Microbial Identification System (MIDI). The predominant cellular fatty acids of [Flexibacter] tractuosus KCTC $2958^{\mathrm{T}}$ and '[Microscilla] sericea' LMG 13021 were iso- $\mathrm{C}_{15: 0}$ ( 36.8 and $26.4 \%$, respectively), iso- $\mathrm{C}_{15: 1}$ (23.0 and $28.6 \%$, respectively) and iso- $\mathrm{C}_{17: 0} \quad 3-\mathrm{OH}(12.2$ and $13.6 \%$, respectively) (Table 1). The two strains could be differentiated by the respective proportions of a number of fatty acids such as $\mathrm{C}_{15: 0}$ and summed feature 3 (comprising $\mathrm{C}_{16: 1} \omega 7$ and/or iso- $\mathrm{C}_{15: 0}$ 2-OH) (Table 1). Isoprenoid quinones were extracted and analysed by using a standard procedure (Minnikin et al., 1984). The major respiratory lipoquinone of [Flexibacter] tractuosus KCTC $2958^{\mathrm{T}}$ and '[Microscilla] sericea' LMG 13021 was MK-7, in line with all other members of the family 'Flammeovirgaceae' (Lau et al., 2006; Nakagawa et al., 1997; Nedashkovskaya et al., 2007; Yoon et al., 2007).

Physiological and biochemical properties of the two strains were examined by using standard procedures and by using API 20E, API 20NE, API CH50 and API ZYM galleries (bioMérieux) according to the manufacturers' instructions, except that the galleries were incubated at $28{ }^{\circ} \mathrm{C}$.

Gram-staining was done as described by Gerhardt et al. (1994). Oxidative or fermentative utilization of glucose was determined on Hugh \& Leifson's medium modified for marine bacteria (Lemos et al., 1985). Degradation of agar, starch, casein, gelatin, cellulose (filter paper and CMcellulose), chitin, DNA, urea and alginic acids, production of flexirubin pigments, growth at different $\mathrm{pH}$, production of acid from carbohydrates, and susceptibility to antibiotics were tested as described previously (Nedashkovskaya et al., 2003). Hydrolysis of Tweens 20, 40 and 80, nitrate reduction, production of hydrogen sulphide, acetoin (Voges-Proskauer reaction) and indole, and presence of $\beta$-galactosidase, oxidase, catalase and alkaline phosphatase activities were tested according to the methods of Gerhardt et al. (1994). The temperature range for growth was assessed in medium A containing $5 \mathrm{~g}$ Bacto peptone 
Table 1. Cellular fatty acid composition (\%) of species of the novel genus Marivirga

Strains: 1, Marivirga tractuosa comb. nov. KCTC $2958^{\mathrm{T}}$; 2, Marivirga sericea nom. rev., comb. nov. LMG $13021^{\mathrm{T}}$. Fatty acids amounting to less than $1 \%$ in both strains are not shown. tr, Trace $(<1 \%)$. All data are from this study.

\begin{tabular}{|c|c|c|}
\hline Fatty acid & 1 & 2 \\
\hline iso- $\mathrm{C}_{11: 0}$ & $\operatorname{tr}$ & 2.7 \\
\hline iso- $\mathrm{C}_{13: 0}$ & 1.2 & $\operatorname{tr}$ \\
\hline iso- $\mathrm{C}_{14: 0}$ & $\operatorname{tr}$ & 1.8 \\
\hline iso- $\mathrm{C}_{15: 1}$ & 23.0 & 28.6 \\
\hline iso- $\mathrm{C}_{15: 0}$ & 36.8 & 26.4 \\
\hline anteiso- $\mathrm{C}_{15: 0}$ & $\operatorname{tr}$ & 1.6 \\
\hline $\mathrm{C}_{15: 0}$ & 4.4 & 2.6 \\
\hline iso- $\mathrm{C}_{16: 1} \mathrm{G}$ & 1.4 & $\operatorname{tr}$ \\
\hline iso- $\mathrm{C}_{16: 0}$ & 3.7 & 1.7 \\
\hline iso- $\mathrm{C}_{15: 0} 3-\mathrm{OH}$ & 2.8 & 4.3 \\
\hline iso- $\mathrm{C}_{16: 0} 3-\mathrm{OH}$ & 2.8 & 2.8 \\
\hline iso- $\mathrm{C}_{17: 0}$ & 1.2 & 1.2 \\
\hline anteiso- $\mathrm{C}_{17: 0}$ & $\operatorname{tr}$ & $1.3-2.3$ \\
\hline iso- $\mathrm{C}_{17: 0} 3-\mathrm{OH}$ & 12.2 & 13.6 \\
\hline Summed feature $3^{\star}$ & 0.8 & 4.5 \\
\hline
\end{tabular}

* Summed feature 3 contains one or more of the following fatty acids which could not be separated by the Microbial Identification System: $\mathrm{C}_{16: 1} \omega 7$ and/or iso- $\mathrm{C}_{15: 0} 2-\mathrm{OH}$.

(Difco), $2 \mathrm{~g}$ Bacto yeast extract (Difco), $1 \mathrm{~g}$ glucose, $0.02 \mathrm{~g}$ $\mathrm{KH}_{2} \mathrm{PO}_{4}$ and $0.05 \mathrm{~g} \mathrm{MgSO}_{4} .7 \mathrm{H}_{2} \mathrm{O}$ per litre of half-strength natural seawater. Tolerance to $\mathrm{NaCl}$ was assessed in medium A prepared with distilled water with $0,0.5,1,2,3,5,6,8,10$ and $12 \%(\mathrm{w} / \mathrm{v}) \mathrm{NaCl}$. Carbon source utilization was tested (i) using commercial API $20 \mathrm{NE}$ identification strips following the instructions of the manufacturer and (ii) using a medium that contained $0.2 \mathrm{~g} \mathrm{NaNO}_{3}, 0.2 \mathrm{~g} \mathrm{NH}_{4} \mathrm{Cl}, 0.05 \mathrm{~g}$ yeast extract (Difco) and $0.4 \%(\mathrm{w} / \mathrm{v})$ carbon source per litre of artificial seawater as described by Suzuki et al. (2001). Spreading growth was observed by cultivation of the strains under high moisture conditions on medium B containing $1 \mathrm{~g}$ Bacto peptone (Difco), $1 \mathrm{~g}$ yeast extract (Difco) and $15 \mathrm{~g}$ agar per litre of half-strength natural seawater. Gliding motility was determined as described by Bowman (2000). Susceptibility to antibiotics was tested as described previously (Nedashkovskaya et al., 2004) using additional discs containing chloramphenicol $(30 \mu \mathrm{g})$, doxycycline $(10 \mu \mathrm{g})$ and erythromycin $(15 \mu \mathrm{g})$.

Physiological, morphological and biochemical characteristics of [Flexibacter] tractuosus KCTC $2958^{\mathrm{T}}$ and '[Microscilla] sericea' LMG 13021 are listed in the genus and species descriptions and in Table 2. The two strains shared most phenotypic features. They were aerobic bacteria motile by gliding, possessing oxidase and catalase activities, decomposing gelatin, DNA and Tween compounds, and utilizing aesculin and arbutin. However, they could be distinguished by several phenotypic traits. [Flexibacter] tractuosus KCTC
$2958^{\mathrm{T}}$ was able to grow at $40{ }^{\circ} \mathrm{C}$ and to utilize L-arabinose, D-glucose, maltose, D-mannose, mannitol, $\mathrm{N}$-acetylglucosamine, adipate, citrate and malate in the API $20 \mathrm{NE}$ gallery but was unable to grow in the presence of $12 \% \mathrm{NaCl}$, whereas '[Microscilla] sericea' LMG 13021 displayed the opposite properties. The phenotypic features differentiating the two strains from related members of the family 'Flammeovirgaceae' are shown in Table 2.

On the basis of the results of the phylogenetic analysis and of the genotypic and phenotypic examination, [Flexibacter] tractuosus KCTC $2958^{\mathrm{T}}$ and '[Microscilla] sericea' LMG 13021 are classified as two distinct species in a new genus, Marivirga gen. nov., as Marivirga tractuosa comb. nov. and Marivirga sericea nom. rev., comb. nov.

Interestingly, two pigmentation variants, designated KMM 6275 and KMM 6276, were isolated from a culture of [Flexibacter] tractuosus KCTC $2958^{\mathrm{T}}$ on MA. Their colonies were yellow and whitish, respectively, compared to the dark-orange pigmented colonies of strain KCTC $2958^{\mathrm{T}}$ (Lewin, 1969). The two variants shared most phenotypic features with [Flexibacter] tractuosus KCTC $2958^{\mathrm{T}}$, but they hydrolysed casein and produced hydrogen sulfide in contrast to the type strain and they also displayed slight differences in the proportions of some fatty acids (data not shown). Moreover, variant KMM 6275 produced acid from D-glucose and maltose. [Flexibacter] tractuosus KCTC $2958^{\mathrm{T}}$ and variants KMM 6275 and KMM 6276 shared $100 \% 16 \mathrm{~S}$ rRNA gene sequence similarity and 95-99\% DNA-DNA relatedness, confirming that they belong to the same species (Wayne et al., 1987).

\section{Description of Marivirga gen. nov.}

Marivirga (Ma.ri.vir'ga L. neut. n. mare the sea, L. fem. n. virga rod, N.L. fem. n. Marivirga a rod that inhabits marine environments).

Rod-shaped cells, motile by gliding. Gram-staining-negative. Do not form endospores. Strictly aerobic. Usually produce non-diffusible orange or yellow pigments. Chemo-organotrophic. Cytochrome oxidase-, catalaseand alkaline phosphatase-positive. The major respiratory quinone is MK-7. Predominant cellular fatty acids (>12\%) are iso- $\mathrm{C}_{15: 0}$, iso- $\mathrm{C}_{15: 1}$ and iso- $\mathrm{C}_{17: 0} 3-\mathrm{OH}$. DNA G+C content is $36-37 \mathrm{~mol} \%$. According to $16 \mathrm{~S}$ rRNA gene sequence analysis, the genus Marivirga is a member of the family 'Flammeovirgaceae' of the phylum Bacteroidetes. The type species is Marivirga tractuosa.

\section{Description of Marivirga sericea nom. rev., comb. nov.}

Marivirga sericea (se.ri'ce.a L. fem. adj. sericea made from or pertaining to silk; N.L. adj. sericea silk-like).

Synonym: 'Microscilla sericea' Lewin 1969, 200.

The main characteristics are as given for the genus. In addition, cells are long, slender and flexible rods 0.4- 
Table 2. Differential phenotypic characteristics of species of the novel genus Marivirga and related members of the family 'Flammeovirgaceae'

Taxa: 1, Marivirga gen. nov. ( $n=2) ; 2$, Fabibacter $(n=1) ; 3$, Fulvivirga $(n=1) ; 4$, Marinoscillum $(n=2) ; 5$, Reichenbachiella ( $n=1)$; 6 , Roseivirga $(n=3)$. n, Number of species; ND, data are not available; v, variable result. Data are from Lau et al. (2006), Nedashkovskaya et al. (2003, 2005a, b, c, 2007, 2008), Reichenbach (1989), Seo et al. (2009) and this study. Data for taxa 1, 3 and 5 and for Roseivirga ehrenbergii and Roseivirga echinicomitans were obtained using the same methods and growth conditions; some of the data for taxa 2 and 4 and for Roseivirga spongicola were obtained using different methods and growth conditions.

\begin{tabular}{|c|c|c|c|c|c|c|}
\hline Characteristic & 1 & 2 & 3 & 4 & 5 & 6 \\
\hline Acetoin production & - & + & ND & $\mathrm{v}$ & - & $\mathrm{v}$ \\
\hline Salinity range for growth $(\% \mathrm{NaCl})$ & $0.5-12$ & $0-12$ & $0-10$ & $0.5-12$ & $1-6$ & $0-16$ \\
\hline \multicolumn{7}{|l|}{ Hydrolysis of: } \\
\hline Agar & - & - & - & - & + & - \\
\hline DNA G $+\mathrm{C}$ content $(\mathrm{mol} \%)$ & $36-37$ & 42.5 & 59.9 & $41-44$ & 44.5 & $40-44$ \\
\hline
\end{tabular}

$0.5 \mu \mathrm{m}$ in diameter and $30-100 \mu \mathrm{m}$ in length or longer. On marine agar, colonies are circular, dark orange, shiny and $2-4 \mathrm{~mm}$ in diameter after $72 \mathrm{~h}$ of incubation. Spreading growth may occur on moist media. Growth is observed at $10-38{ }^{\circ} \mathrm{C}$ and in the presence of $0.5-12 \% \mathrm{NaCl}$, with optimal growth at $28-30{ }^{\circ} \mathrm{C}$ and with $4-6 \% \mathrm{NaCl}$. Flexirubin-type pigments are not produced. Arginine dihydrolase, ornithine decarboxylase, lysine decarboxylase and tryptophan deaminase activities are absent. Nitrate is not reduced. Indole, $\mathrm{H}_{2} \mathrm{~S}$ and acetoin (Voges-Proskauer reaction) are not produced. Casein, gelatin, Tweens 20, 40 and 80 and DNA are hydrolysed. Agar, starch, urea, cellulose (CM-cellulose and filter paper) and chitin are not hydrolysed. Acid is not produced from L-arabinose, cellobiose, L-fucose, D-galactose, D-glucose, glycerol, lactose, maltose, melibiose, raffinose, L-rhamnose, L-sorbose, sucrose, trehalose, DL-xylose, $\mathrm{N}$-acetylglucosamine, citrate, acetate, fumarate, malate, adonitol, dulcitol, inositol or mannitol. In the API $50 \mathrm{CH}$ gallery, acid is produced only from aesculin and arbutin. D-Glucose, D-mannose and sucrose are utilized but L-arabinose, lactose, inositol, sorbitol, mannitol, malonate and citrate are not utilized. In the API ZYM gallery, alkaline phosphatase, esterase (C4), esterase lipase (C8), leucine arylamidase, valine arylamidase, cystine arylamidase, $\alpha$-chymotrypsin, acid phosphatase, naphthol-AS-BI-phosphohydrolase, $\beta$-galactosidase and $\alpha$ - and $\beta$-glucosidase activities are present, but lipase (C14), trypsin, $\alpha$-galactosidase, $\beta$-glucuronidase, $N$ acetyl- $\beta$-glucosaminidase, $\alpha$-mannosidase and $\alpha$-fucosidase activities are absent. Susceptible to ampicillin $(10 \mu \mathrm{g})$, benzylpenicillin $(10 \mathrm{U})$, carbenicillin $(100 \mu \mathrm{g})$, chloramphenicol $(30 \mu \mathrm{g})$, doxycycline $(10 \mu \mathrm{g})$, erythromycin $(15 \mu \mathrm{g})$, lincomycin $(15 \mu \mathrm{g})$, oleandomycin $(15 \mu \mathrm{g})$ and tetracycline $(30 \mu \mathrm{g})$; resistant to gentamicin $(10 \mu \mathrm{g})$, kanamycin $(30 \mu \mathrm{g})$, neomycin $(30 \mu \mathrm{g})$, polymixin $(300 \mathrm{U})$ and streptomycin $(30 \mu \mathrm{g})$. The predominant cellular fatty acids $(>4 \%)$ are iso- $\mathrm{C}_{15: 0}$, iso- $\mathrm{C}_{15: 1}$, iso-
$\mathrm{C}_{17: 0} 3-\mathrm{OH}$, iso- $\mathrm{C}_{15: 0} 3-\mathrm{OH}$ and summed feature 3 (comprising $\mathrm{C}_{16: 1} \omega 7$ and/or iso- $\mathrm{C}_{15: 0} 2-\mathrm{OH}$ ). The detailed fatty acid composition is given in Table 1 . The DNA G $+\mathrm{C}$ content of the type strain is $37.1 \mathrm{~mol} \%$.

The type strain, LMG $13021^{\mathrm{T}}\left(=\right.$ ATCC $23182^{\mathrm{T}}=$ NBRC $15983^{\mathrm{T}}=\mathrm{NCIMB} 1403^{\mathrm{T}}$ ), was isolated from marine aquarium outflow, La Jolla, California, USA.

\section{Description of Marivirga tractuosa comb. nov.}

Marivirga tractuosa (trac.tu.o'sa L. fem. adj. tractuosa that draws to itself, gluey, viscous).

Synonyms: 'Microscilla tractuosa' Lewin 1969, 199; Flexibacter tractuosus (Lewin 1969) Leadbetter 1974.

The main characteristics are as given for the genus. In addition, cells are long, slender and flexible rods 0.4$0.5 \mu \mathrm{m}$ in diameter and $10-50 \mu \mathrm{m}$ in length or longer. On marine agar, colonies are circular, shiny and $2-4 \mathrm{~mm}$ in diameter after $72 \mathrm{~h}$ of incubation. Colonies are usually dark-orange-coloured but whitish or yellow-pigmented variants may occur. Spreading growth may occur on moist media. Growth is observed at $10-40{ }^{\circ} \mathrm{C}$ and with $0.5-10 \%$ $\mathrm{NaCl}$, with optimal growth at $28-32{ }^{\circ} \mathrm{C}$ and with $4-7 \%$ $\mathrm{NaCl}$. Flexirubin-type pigments are not produced. Arginine dihydrolase, ornithine decarboxylase, lysine decarboxylase and tryptophan deaminase activities are absent. Nitrate is not reduced. Indole and acetoin (Voges-Proskauer reaction) are not produced. Gelatin, Tweens 20, 40 and 80 and DNA are hydrolysed. Agar, starch, urea, cellulose (CMcellulose and filter paper) and chitin are not hydrolysed. Acid is not produced from L-arabinose, cellobiose, Lfucose, D-galactose, glycerol, lactose, melibiose, raffinose, L-rhamnose, L-sorbose, sucrose, trehalose, DL-xylose, $\mathrm{N}$ acetylglucosamine, citrate, acetate, fumarate, malate, adonitol, dulcitol, inositol or mannitol. In the API $50 \mathrm{CH}$ gallery, acid is produced only from aesculin and arbutin. 
Production of hydrogen sulfide, hydrolysis of casein and oxidation of D-glucose and maltose are variable. Citrate is utilized but lactose, inositol, gluconate, caprate, phenylalanine and malonate are not. Utilization of arabinose, Dglucose, D-mannose, sucrose, mannitol, $\mathrm{N}$-acetylglucosamine, maltose, adipate, malate and sorbitol is variable. In the API ZYM gallery, alkaline phosphatase, esterase (C4), esterase lipase (C8), leucine arylamidase, valine arylamidase, cystine arylamidase, $\alpha$-chymotrypsin, acid phosphatase, naphthol-AS-BI-phosphohydrolase, $\beta$-galactosidase and $\alpha$ - and $\beta$-glucosidase activities are present, but lipase (C14), trypsin, $\alpha$-galactosidase, $\beta$-glucuronidase, $N$-acetyl$\beta$-glucosaminidase, $\alpha$-mannosidase and $\alpha$-fucosidase activities are absent. Susceptible to ampicillin $(10 \mu \mathrm{g})$, benzylpenicillin $(10 \mathrm{U})$, carbenicillin $(100 \mu \mathrm{g})$, chloramphenicol $(30 \mu \mathrm{g})$, doxycycline $(10 \mu \mathrm{g})$, erythromycin $(15 \mu \mathrm{g})$, lincomycin $(15 \mu \mathrm{g})$, oleandomycin $(15 \mu \mathrm{g})$ and tetracycline $(30 \mu \mathrm{g})$; resistant to gentamicin $(10 \mu \mathrm{g})$, kanamycin $(30 \mu \mathrm{g})$, neomycin $(30 \mu \mathrm{g})$, polymixin $(300 \mathrm{U})$ and streptomycin $(30 \mu \mathrm{g})$. The predominant cellular fatty acids $(>4 \%)$ are iso- $\mathrm{C}_{15: 0}$, iso- $\mathrm{C}_{15: 1}$, iso- $\mathrm{C}_{17: 0} 3-\mathrm{OH}$ and $\mathrm{C}_{15: 0}$. The detailed fatty acid composition is given in Table 1 . The DNA G $+\mathrm{C}$ content of the type strain is $36.1 \mathrm{~mol} \%$.

The type strain, KCTC $2958^{\mathrm{T}}\left(=\mathrm{ATCC} 23168^{\mathrm{T}}=\mathrm{CIP}\right.$ $106410^{\mathrm{T}}=\mathrm{DSM} 4126^{\mathrm{T}}=$ NBRC $15989^{\mathrm{T}}=$ NCIMB $1408^{\mathrm{T}}$ $=\mathrm{VKM} \mathrm{B}-1430^{\mathrm{T}}$ ), was isolated from a beach sand sample, collected from Nhatrang (South China Sea), Vietnam.

\section{Acknowledgements}

This research was supported by grants from the Presidium of the Russian Academy of Sciences 'Molecular and Cell Biology', the Presidium of the Far-Eastern Branch of the Russian Academy of Sciences no. 09-III-A-06-227 and the State Contract 02.518.11.7169 from the Federal Agency for Science and Innovations of the Russian Federation. S. B. K. and K. S. B. acknowledge support from the Survey of Indigenous Biological Resources of Korea Program sponsored by the National Institute of Biological Resources (NIBR) and from the KRIBB Research Initiative Program (KGM2230711), respectively.

\section{References}

Bowman, J. P. (2000). Description of Cellulophaga algicola sp. nov., isolated from the surfaces of Antarctic algae, and reclassification of Cytophaga uliginosa (ZoBell and Upham 1944) Reichenbach 1989 as Cellulophaga uliginosa comb. nov. Int J Syst Evol Microbiol 50, 18611868.

De Ley, J., Cattoir, H. \& Reynaerts, A. (1970). The quantitative measurement of DNA hybridization from renaturation rates. Eur $J$ Biochem 12, 133-142.

Felsenstein, J. (1993). PHYLIP (phylogeny inference package), version 3.5c. Distributed by the author. Department of Genome Sciences, University of Washington, Seattle, USA.

Gerhardt, P., Murray, R. G. E., Wood, W. A. \& Krieg, N. R. (editors) (1994). Methods for General and Molecular Bacteriology. Washington, DC: American Society for Microbiology.

Hosoya, S. \& Yokota, A. (2007). Reclassification of Flexibacter aggregans (Lewin 1969) Leadbetter 1974 as a later heterotypic synonym of Flexithrix dorotheae Lewin 1970. Int J Syst Evol Microbiol 57, 1086-1088.

Jukes, T. H. \& Cantor, C. R. (1969). Evolution of protein molecules. In Mammalian Protein Metabolism, vol. 3, pp. 21-132. Edited by H. N. Munro. New York: Academic Press.

Khan, S. T., Nakagawa, Y. \& Harayama, S. (2007). Sediminitomix flava gen. nov., sp. nov., of the phylum Bacteroidetes, isolated from marine sediment. Int J Syst Evol Microbiol 57, 1689-1693.

Kluge, A. G. \& Farris, J. S. (1969). Quantitative phyletics and the evolution of anurans. Syst Zool 18, 1-32.

Lau, S. C. K., Tsoi, M. M. Y., Li, X., Plakhotnikova, I., Dobretsov, S., Wu, M., Wong, P.-K., Pawlik, J. R. \& Qian, P.-Y. (2006). Description of Fabibacter halotolerans gen. nov., sp. nov. and Roseivirga spongicola sp. nov., and reclassification of [Marinicola] seohaensis as Roseivirga seohaensis comb. nov. Int J Syst Evol Microbiol 56, 1059-1065.

Leadbetter, E. R. (1974). Genus II Flexibacter Soriano 1945, Lewin 1969, 192 emend. mut. char. In Bergey's Manual of Determinative Bacteriology, 8th edn, pp. 105-107. Edited by R. E. Buchanan \& N. E. Gibbons. Baltimore: Williams \& Wilkins.

Lemos, M. L., Toranzo, A. E. \& Barja, J. L. (1985). Modified medium for oxidation-fermentation test in the identification of marine bacteria. Appl Environ Microbiol 49, 1541-1543.

Lewin, R. A. (1969). A classification of flexibacteria. J Gen Microbiol 58, 189-206.

Ludwig, W., Euzéby, J. \& Whitman, W. B. (2008). Draft Taxonomic Outline of the Bacteroidetes, Planctomycetes, Chlamydiae, Spiroehaetes, Fibrobacteres, Fusobacteria, Acidobacteria, Verrucomicrobia, Dictyoglomi, and Gemmatimonadetes for Volume 4 of the second edition of Bergey's Manual of Systematic Bacteriology (http://www. bergeys.org/outlines.html).

Marmur, J. (1961). A procedure for the isolation of deoxyribonucleic acid from microorganisms. J Mol Biol 3, 208-218.

Marmur, J. \& Doty, P. (1962). Determination of the base composition of deoxyribonucleic acid from its thermal denaturation temperature. J Mol Biol 5, 109-118.

Minnikin, D. E., O’Donnell, A. G., Goodfellow, M., Alderson, G., Athalye, M., Schaal, A. \& Parlett, J. H. (1984). An integrated procedure for the extraction of bacterial isoprenoid quinones and polar lipids. J Microbiol Methods 2, 233-241.

Muramatsu, Y., Takahashi, M., Kaneyasu, M., lino, T., Suzuki, K. \& Nakagawa, Y. (2010). Persicobacter psychrovividus sp. nov., isolated from shellfish, and emended descriptions of the genus Persicobacter and Persicobacter diffluens. Int J Syst Evol Microbiol 60, 1735-1739.

Nakagawa, Y., Hamana, K., Sakane, T. \& Yamasato, K. (1997). Reclassification of Cytophaga aprica (Lewin 1969) Reichenbach 1989 in Flammeovirga gen. nov. as Flammeovirga aprica comb. nov. and of Cytophaga diffluens (ex Stanier 1940; emend. Lewin 1969) Reichenbach 1989 in Persicobacter gen. nov as Persicobacter diffluens comb. nov. Int J Syst Bacteriol 47, 220-223.

Nakagawa, Y., Sakane, T., Suzuki, M. \& Hatano, K. (2002). Phylogenetic structure of the genera Flexibacter, Flexithrix, and Microscilla deduced from $16 \mathrm{~S}$ rRNA sequence analysis. J Gen Appl Microbiol 48, 155-165.

Nedashkovskaya, O. I., Suzuki, M., Vysotskii, M. V. \& Mikhailov, V. V. (2003). Reichenbachia agariperforans gen. nov., sp. nov., a novel marine bacterium in the phylum Cytophaga-FlavobacteriumBacteroides. Int J Syst Evol Microbiol 53, 81-85.

Nedashkovskaya, O. I., Kim, S. B., Han, S. K., Rhee, M. S., Lysenko, A. M., Falsen, E., Frolova, G. M., Mikhailov, V. V. \& Bae, K. S. (2004). Ulvibacter litoralis gen. nov., sp. nov., a novel member of the family Flavobacteriaceae isolated from the green alga Ulva fenestrata. Int $J$ Syst Evol Microbiol 54, 119-123. 
Nedashkovskaya, O. I., Kim, S. B., Lee, D. H., Lysenko, A. M., Shevchenko, L. S., Frolova, G. M., Mikhailov, V. V., Lee, K. H. \& Bae, K. S. (2005a). Roseivirga ehrenbergii gen. nov., sp. nov., a novel marine bacterium of the phylum 'Bacteroidetes', isolated from the green alga Ulva fenestrata. Int J Syst Evol Microbiol 55, 231-234.

Nedashkovskaya, O. I., Kim, S. B., Lysenko, A. M., Park, M. S., Mikhailov, V. V., Bae, K. S. \& Park, H. Y. (2005b). Roseivirga echinicomitans sp. nov., a novel marine bacterium isolated from the sea urchin Strongylocentrotus intermedius, and emended description of the genus Roseivirga. Int J Syst Evol Microbiol 55, 1797-1800.

Nedashkovskaya, O. I., Kim, S. B., Suzuki, M., Shevchenko, L. S., Lee, M. S., Lee, K. H., Park, M. S., Frolova, G. M., Oh, H. W., Bae, K. S., Park, H. Y. \& Mikhailov, V. V. (2005c). Pontibacter actiniarum gen. nov., sp. nov., a novel member of the phylum 'Bacteroidetes', and proposal of Reichenbachiella gen. nov. as a replacement for the illegitimate prokaryotic generic name Reichenbachia Nedashkovskaya et al. 2003. Int J Syst Evol Microbiol 55, 2583-2588.

Nedashkovskaya, O. I., Kim, S. B., Shin, D. S., Beleneva, I. A. \& Mikhailov, V. V. (2007). Fulvivirga kasyanovii gen. nov., sp. nov., a novel member of the phylum Bacteroidetes isolated from seawater in a mussel farm. Int J Syst Evol Microbiol 57, 1046-1049.

Nedashkovskaya, O. I., Kim, S. B., Lysenko, A. M., Kalinovskaya, N. I. \& Mikhailov, V. V. (2008). Reclassification of Roseivirga seohaensis (Yoon et al. 2005) Lau et al. 2006 as a later synonym of Roseivirga ehrenbergii Nedashkovskaya et al. 2005 and emendation of the species description. Int J Syst Evol Microbiol 58, 1194-1197.

Reichenbach, H. (1989). Genus Flexibacter Soriano 1945, 92, ${ }^{\mathrm{AL}}$ emend. In Bergey's Manual of Systematic Bacteriology, vol. 3, pp. 2061-2071. Edited by J. T. Staley, M. P. Bryant, N. Pfennig \& J. G. Holt. Baltimore: Williams \& Wilkins.

Saitou, N. \& Nei, M. (1987). The neighbor-joining method: a new method for reconstructing phylogenetic trees. Mol Biol Evol 4, 406425.

Seo, H.-S., Kwon, K. K., Yang, S.-H., Lee, H.-S., Bae, S. S., Lee, J.-H. \& Kim, S.-J. (2009). Marinoscillum gen. nov., a member of the family
'Flexibacteraceae', with Marinoscillum pacificum sp. nov. from a marine sponge and Marinoscillum furvescens nom. rev., comb. nov. Int J Syst Evol Microbiol 59, 1204-1208.

Skerman, V. B. D., McGowan, V. \& Sneath, P. H. A. (editors) (1980). Approved lists of bacterial names. Int J Syst Bacteriol 30, 225420.

Srisukchayakul, P., Suwanachart, C., Sangnoi, Y., Kanjana-Opas, A., Hosoya, S., Yokota, A. \& Arunpairojana, V. (2007). Rapidithrix thailandica gen. nov., sp. nov., a marine gliding bacterium isolated from samples collected from the Andaman sea, along the southern coastline of Thailand. Int J Syst Evol Microbiol 57, 2275-2279.

Suzuki, M., Nakagawa, Y., Harayama, S. \& Yamamoto, S. (2001). Phylogenetic analysis and taxonomic study of marine Cytophaga-like bacteria: proposal for Tenacibaculum gen. nov. with Tenacibaculum maritimum comb. nov., and Tenacibaculum ovolyticum comb. nov., and description of Tenacibaculum mesophilum sp. nov. and Tenacibaculum amylolyticum sp. nov. Int J Syst Evol Microbiol 51, 1639-1652.

Takahashi, M., Suzuki, K. \& Nakagawa, Y. (2006). Emendation of the genus Flammeovirga and Flammeovirga aprica with the proposal of Flammeovirga arenaria nom. rev., comb. nov. and Flammeovirga yaeyamensis sp. nov. Int J Syst Evol Microbiol 56, 2095-2100.

Wayne, L. G., Brenner, D. J., Colwell, R. R., Grimont, P. A. D., Kandler, O., Krichevsky, M. I., Moore, L. H., Moore, W. E. C., Murray, R. G. E. \& other authors (1987). International Committee on Systematic Bacteriology. Report of the ad hoc committee on reconciliation of approaches to bacterial systematics. Int J Syst Bacteriol 37, 463-464.

Yoon, J., Ishikawa, S., Kasai, H. \& Yokota, A. (2007). Perexilibacter aurantiacus gen. nov., sp. nov., a novel member of the family 'Flammeovirgaceae' isolated from sediment. Int J Syst Evol Microbiol 57, 964-968.

Yoon, J., Matsuo, Y., Kasai, H. \& Yokota, A. (2008). Limibacter armeniacum gen. nov., sp. nov., a novel representative of the family 'Flammeovirgaceae' isolated from marine sediment. Int J Syst Evol Microbiol 58, 982-986. 